\title{
Gypsy/Roma diasporas. A comparative perspective*
}

At the core of non-Gypsy models of Gypsyness - in particular, those upheld by linguists and folklorists in the nineteenth and early twentieth centuries, and also by academics such as anthropologists, historians or sociologists then and later - lies a concern with the unity of the Gypsies. This unity has been both phrased and challenged within a variety of frameworks, including cultural, linguistic and biological (Okely 1983; Mayall 1988; Lucassen 1991). ${ }^{1}$ Academics and folklorists have, for the last one hundred years, debated whether Gypsies indeed form one people given the wide differences in historical development, life-style, world-views and modes of interaction with the dominant population that characterise Gypsies in different areas of the world, and given the fact that different Gypsy groups very often do not recognise each other as belonging to the same social and moral community (Williams 1984; Liégeois 1994). At stake is the issue - of key interest also to Roma activists - of whether Gypsies can be said to make up a transnational, global diaspora when, unlike the archetype of the diasporic population, the Jews, they rarely claim for themselves a land of origin, a history, or any kind of overarching political project to debate or share.

Even today, when Roma activists are increasingly drawing on the political discourses of the dominant society to call for the full extension of human rights to Gypsies everywhere, there is little grass roots support for these appeals for the international recognition of the Gypsies' shared history of persecution and even less for the creation of a Roma state - Romanistan. Instead, according to the ethnographic record, few so-called Gypsy groups display any interest in bringing about imaginative or practical cohesion with each other (cf. Williams 1984; Stewart 1997; Gay y Blasco 1999). For over five hundred years, the Gypsy diaspora has been characterised by its extreme political and structural fragmentation, and by the weakness or even absence of any overarching Gypsy imagined community.

Rather than addressing the theoretical issue of whether Gypsies worldwide do indeed form one people, my aim here is to take a firm ethnographic approach, dealing with the imaginative and practical links that a group of Spanish Gypsies or Gitanos from Jarana, ${ }^{2}$ a neighbourhood in the periphery of Madrid, make with other

* This article was presented at a workshop on Politico-Religious Diasporas, chaired by Steven Vartovek, at the sixth Biennial Conference of the European Association of Social Anthropologists, Krakow July 2000. I wish to thank the participants of the workshop, Huon Wardle and two anonymous reviewers for Social Anthropology for their useful comments.

1 It's most popular and persistent incarnation is the dichotomy 'authentic Romany' versus 'fake drop-outs' which in recent years has underlain the discourse on so-called 'authentic' and 'bogus' asylum-seekers (Clark and Campbell 2000).

2 The names 'Jarana' and 'La Fresneda' are pseudonyms, as are the names of all people in the article. 
Gitanos and Gypsies elsewhere. Thus, I explore how these Gitanos - who are, I believe, representative of many other poor, urban Gitanos throughout Spain (cf. Gamella 1996; San Román 1994; Anta Félez 1994) - position themselves vis-à-vis other Gitanos in Spain and vis-à-vis Gypsies elsewhere: What kind of diaspora do the people of Jarana see themselves as belonging to? The context to my investigation is the very rapid spread of Gypsy Pentecostal Evangelism throughout western Europe and, to a much lesser extent and only for comparative purposes, the growth of Roma international political activism. These two movements - albeit in very different ways and with some significant internal variations - call for the unity of all Gypsies worldwide and attempt to put into place the mechanisms for its realisation. However, whereas the Gitano Evangelical Church has been extremely successful in capturing the imagination of the people of Jarana - between a third and half of the population of the neighbourhood have converted during the last ten years - Roma activism has bypassed them completely, and they know next to nothing of its existence, aims or methods.

At the heart of my discussion lies a concern with the relationship between the imagined community and the social and political relations it both depends upon and sustains (cf. Gellner 1983; Anderson 1991). I put forward three Gypsy diasporic modalities - a non-convert, non-activist and kin-oriented; a convert and communitarian; and an activist and universalising - and argue that each involves a particular way of conceiving 'the Gitanos/Gypsies/Roma' or 'the Gitano/Gypsy/Roma people' (in Jarana, el pueblo Gitano) as a community as well as a distinctive pattern of sociopolitical relations.

Although my main concern is with the growth of Gitano Pentecostalism, I also want to emphasise that each of these three modalities constitutes a distinct attempt by Gypsies/Roma to position themselves within the non-Gypsy world - a world that, at least in Jarana, they perceive as in the midst of a rapid, radical and unprecedented transformation. While I do not address this issue in the detail it merits, it will be obvious to the reader that the ethnographic material below raises the question of whether all contemporary expressions of Gypsyness are succumbing to the ravages of globalisation (cf. Wilks 1995), borrowing their form and their content too from dominant Euro-American discourses of identity - from North-American Christian fundamentalism in the Pentecostal case and from the realm of international identity politics in the case of Roma activists.

\section{A terminological caveat. 'Gypsies' and 'Roma'}

In recent years, the word 'Gypsy' has lost ground to the word 'Roma' in texts and discourses by and about Gypsies/Roma. 'Gypsy' has increasingly come to be seen as a pejorative term that reflects the world-views and oppression practices of the dominant population (Liégeois 1994: 258). 'Roma', on the other hand, is meant to reflect the rich heritage and cultural dignity and distinctiveness of an oppressed but also resisting people, as well as their common history and identity of interests. The Gitanos I worked with in Jarana, however, have never heard the word 'Roma', and would not know what it meant, let alone that it might be used to refer to them alongside thousands, if not millions, of others. Although the word 'Gitano' - whose most direct English translation is 'Gypsy' - is often used by non-Gypsies as a pejorative word, to the Gitanos themselves it simply defines who they are and it is therefore full of posi- 
tive connotations. ${ }^{3}$ To them, it is the word 'Payo' (non-Gitano) that is pejorative and negative - and, of course, the non-Gitanos are ignorant of this fact and use the word 'Payo' with pride. Given that the Gitanos of Jarana would not recognise the word 'Roma' and would, I believe, not approve of the forms of mobilisation that accompany its use, and given also the fact that they would not be happy to define themselves except as 'Gitanos', it is that word that I keep to refer to them and their perspectives. I take up the word 'Roma' to refer to the activists and their perspectives. By insisting on this differentiation, I want to reflect also the fact that there is a large contingent of Gypsies/Roma who either are unaware of the Roma activist movement or who would not identify with its aims.

\section{The context}

In 1992, when I began my fieldwork in Jarana, the local government in Madrid found itself in the midst of a massive campaign to solve once and for all 'the Gitano issue' (la cuestion gitana). Gitanos had moved in large numbers to the capital since the 1950s when, alongside other rural migrants, they responded to the country's growing industrialisation and the concomitant decline of the countryside. Once in Madrid, they were pushed by successive administrations to the most isolated urban fringes. There they had little option but to build shanty towns that have come to be seen by non-Gypsies as master symbols of urban poverty and decay.

In the late 1980s the local government made a complete census of the Gitano population living in shanty towns. Those Gitanos who were classified as most reluctant or most unable to live among the non-Gypsies were to be temporarily housed in Special Colonies for Marginal Population (Colonias Especiales para Población Marginal). Once there, the Gitanos would be subjected to intensive social work and compulsory re-education schemes. Once their re-education was complete, the orthodoxy was that these Gitanos would be resettled among the non-Gypsies. Jarana was built in 1989 as one such 'special colony'. When I begun my fieldwork, 80 Gitano and mixed families from all over the city had been living there for three years. Most were very poor and earned a meagre living by selling fruit, vegetables and textiles on the streets, by door-to-door scrap collecting or by scavenging at a municipal rubbish dump. All had to attend compulsory re-education classes in the local social assistance

3 How disjoined the aims and perspectives of Roma activists are from those of the Gitanos of Jarana is well reflected by Liégeois' account of the decision, by the delegates of the first World Romani Congress, which took place in London in 1972, to reject 'the terms Tsiganes, Zigeuner, Gitanos, Gypsies et al., which are not their own and do not coincide with reality anywhere, opting instead for the term Rom' (1994: 258). By contrast, reflecting on the self-definitions of different Gypsy groups, the linguist of Romani, Anthony Grant, has emphasised the fact that 'If Gitanos in Spain did know the terms Rom or Roma, they would probably associate them with the non-Spanish Gypsies who entered Spain in the late nineteenth and early twentieth centuries (the types referred to as 'Húngaros' - Lovara, Kalderara, Churara etc.). Words deriving from 'rom' simply meant 'husband' in Caló, and Romñí is 'wife'. It is the same with the Sinte in Germany, who would never refer to themselves as Roma, and who indeed referred to Gypsies who spoke unintelligible dialects (say Lovari or Czech Romani) as 'lalere Sinte', 'mute Sinte', not 'lalere Roma'. Groups who did not use a self-designation based on 'Rom' but who do so now have acquired it through politicised 'selfawakening' of the 'back to India' variety' (Anthony Grant, personal communication, 7 November 2000). 
centre. Then, in 1995, the priorities of the local government changed and Jarana was de-classified as temporary accommodation. Although the social workers have long left and the classrooms are closed, the Gitanos who were resettled in Jarana in 1990 have been living there for over ten years. There is no likelihood that housing for them will be made available anywhere else.

Between a third and half of all the Gitanos who live in Jarana declare themselves converts to Pentecostalism ${ }^{4}$ - in fact, a handful converted in the 1960s in response to the first mission that was carried out in the city. The Gitano Evangelical Church, Iglesia Evangélica de Filadelfia, is part of the wider Gypsy Pentecostal movement that has swept through Western Europe over the last twenty years. In the early 1960s, French Gypsy missionaries, themselves the product of a mission campaign carried out by a non-Gypsy in the 1950s, came down to the Peninsula to preach 'the Word of God' to the Gitanos (Williams 1991; Jordán Pemán 1990; Cano 1981). The Spanish Gypsy Pentecostal movement began slowly to grow, was recognised by the state as a religious organisation in 1969 and, as has happened in France, England and Italy, experienced its greatest expansion during the late 1980s, 1990s and early 2000s. Currently there are no data as to the number of Gitano converts - who call themselves cristianos (Christians) or aleluyas - but there is a church in every area where Gitanos live in any significant numbers. In Jarana Pentecostalism is, even if only indirectly, part of the daily experience of all the people of the neighbourhood.

These developments have taken place against a complex framework of radical social, economic and cultural change in the country as a whole. During the last decade, as well as becoming increasingly incorporated in the European Union, Spain has become a target for migration from Latin America, the Spanish-speaking Caribbean, the Philippines and North Africa. Social relations are in a process of profound change, and mores and ways of perceiving the nation, the local community and the self are similarly being transformed. The Gitanos, as a distinct group competing for space and resources in the crowded peripheries of the large cities - a group that is perceived to reject the dominant work ethic and signs of communal identity (López Varas and Fresnillo Pato 1995) - have come under growing pressure to assimilate into the majority. They have been the object of both large numbers of violent protests and of unparalleled attempts towards institutionalisation: through an ever-growing expansion of the social services the Gitanos have been brought, more than ever before, under the control of the state.

\section{The Gitano diaspora. Non-convert practices and perspectives}

I am sitting by the kitchen window, peering through the curtains into the patio. I begun my fieldwork only two months ago and do not want to interrupt the important proceedings outside. A large group of Gitanos has gathered. Many belong to the Ramones patrigroup (raza), who live

4 Convert identity often fluctuates rather than being fixed: a person may accept Christ as their personal saviour, then go on attending the local church regularly for a period, and finally lapse and no longer consider themselves converted. They may never return or, after a few years, they may return to attending the local church, be baptised and become extremely active for years on end. Of course, there is a substantial core of very committed converts whose allegiance to the Church does not fluctuate, at least not visibly. 
locally, and the others are Pájaros, from another area of Madrid. The Pájaros are in the midst of a blood feud (ruina). Isabel, a young Pájaro woman, and her brother Paco were shot at by Isabel's husband, who suspected her of having a lover. Isabel was unharmed but Paco was wounded in the leg. He nonetheless managed to get hold of a firearm and wound Isabel's husband, who has just died in hospital, and his father, who is critically ill. Although their guilt is not clear, the Pájaros have had to leave their neighbourhood and all their possessions behind in an attempt to escape retaliation. They have come to Jarana because they can count on the Ramones, to whom they are linked by a succession of marriage ties. Not only is Tía Rosa, the wife of the Ramones patriarch, the sister of the elderly leader of the Pájaros: her granddaughter Feli is Paco's wife, and although a Ramona, is as liable according to Gitano custom - the 'Gitano laws' (leyes Gitanas) - of being the object of life-threatening retaliation as her husband and affines.

Half way through the afternoon I hear shouts of 'The old Gitanos! The old Gitanos are coming!' Four cars arrive in the street outside, and four elderly Gitanos, their small retinues around them, get out and enter the patio. They are all wearing fedoras and carrying elaborately carved walking sticks. Ramones and Pájaros make way for them and allow their own elders to greet them. The visitors are 'men of respect' (bombres de respeto) - old Gitanos from neutral patrigroups, well known for their knowledge of the 'Gitano laws', who have been called to act as mediators. They have already visited the relatives of the victims and hope to arrive to a solution that will satisfy all the parties involved. After much heated discussion, an agreement is reached: the Pájaros will from now onwards refrain from entering the south of the city, below an imaginary line that stretches east to west across the Rastro flea-market. They will have to abandon their homes for good and will also lose access to some of their best vending and scrap collecting locations. The aim of the settlement is to prevent the Pájaros and their 'enemies' (called contrarios by the Gitanos) from ever setting eyes on each other again. If they do, the assumption is that their fury and hate for each other will drive them to kill, and the fighting will be rekindled.

Unlike many other acephalous minorities whose singularity and lifestyle survive under the pressure of dominant majorities, the Gitanos who live in Jarana do not premise their image of themselves as part of 'the Gitano people' (el pueblo Gitano) on an ideal of unity. Indeed, ever since their presence in the Iberian peninsula was first documented in the early fifteenth century, relations among Gitanos have been characterised by a lack of social and political cohesion, and by the weakness of any frames of communal reference external to Gitano individuals themselves. Those first Gitanos moved around the country in clearly defined small groups that claimed no political affinity with each other (San Román 1994: 13-15; Sánchez Ortega 1986: 18; Leblon 1987: 17). Today, physical dispersal and sociopolitical fragmentation are equally essential to the Gitanos' experiences of, and ideas about, Gypsyness. Not only are there no structures that would bring all Gitanos together under the umbrella of a shared political project, such as a state or attachment to a territory: the Gitanos are also separated from each other through such factors as ethnic and religious affiliations, and levels of economic success, all of which weigh heavily on their imaginative configurations of themselves. However, it is the fact of belonging to a closely knit group of kin - a raza or patrigroup where relations are ideally governed by love, by altruism and by the absence of individual juridical personality - that is invoked in Jarana as the reason why Gitanos must restrict their contact with unrelated, potentially threatening others. Maternal kin and affines are main objects of affection and are seen as much less of a threat than non-kin, but ultimately they belong to a different raza and may in adverse circumstances turn into contrarios. This was the case for Isabel's children, who belonged to their father's raza and for whom all Pájaros, including their mother, were now enemies.

Blood feuds like the one between the Pájaros and their contrarios are solved through the separation in space of the groups involved, which are restricted to particular areas of 
the city and even beyond. Because they believe that any quarrel, no matter how small, can easily develop into a full blown feud, Gitanos often live with their backs to each other, purposefully restricting daily sociability to their relatives (San Román 1994; Anta Félez 1994; Gay y Blasco 1999). By distancing themselves from their neighbours these Gitanos not only attempt to avoid potentially conflictive situations: they also assert their attachment to their kin and reject cohesion with non-kin as foreign to the Gitanos and part of the Payo 'way of being' (manera de ser). Although the blood feud and the regimented process of mediation that follows it work to bridge this fragmentation, neither is aimed at reconciliation or at the realisation of social harmony. Rather, by separating the parties and forbidding them any contact for as long as memory of the feud remains, feuding and mediation enshrine social and political antagonism as essential to the 'Gitano way of being' - the only way of being that is properly human and morally and aesthetically satisfying.

And yet, in spite of the basic feeling of isolation that governs this aspect of Gitano life - where both the despised and hated Payos and other Gitanos are seen as threatening enemies - the sense that the people of Jarana have that they share with each other and with Gitanos everywhere who they are is extremely strong. This sense of identity and togetherness, however, is not anchored in any notion of community easily comparable to those of the non-Gypsies around them: territory, history and attachment to a state, and not merely social harmony, are absent from their self-conceptualisations. Similarly, as I have explained at length elsewhere (Gay y Blasco 1999), the people of Jarana do not see themselves as belonging to a society in the traditional anthropological meaning of the term: they have no concept of a structure of statuses that individuals would occupy and vacate upon death, and also disregard any notion that parochial interests should or would work to sustain the group at large.

In fact, 'community' - as an analytical translation for the Gitano concept of pueblo (people) - refers here not to 'communion' but to 'commonality'. The emphasis is on mimesis and moral correspondence and, in particular, on the assumption that, within the bounds of the nurturing environment of the raza, each Gitano man and woman upholds the Gitano morality. It is the person, as performer of Gitano custom - the leyes Gitanas (Gitano laws) - who sustains the Gitanos' shared sense of community. Divisions, fragmentations and indeed violence and dissent are not seen as impediments to the realisation of this entity, and there is no awareness that they must be resolved in order for the sense of moral commonality to exist.

The specific characteristics of the Gitanos' image of themselves as a group, different from and living amidst the non-Gypsies, correspond to the dispersed nature of their everyday life: 'the Gitano people' (el pueblo Gitano) is, in their eyes, a scattered aggregate of persons, of undefined size, origin and location, who are similarly positioned vis-à-vis the rest of the world and who uphold the 'Gitano laws'. Although they know that there are other kinds of Gypsies who live outside Spain, and indeed believe that there are Gitano-like populations 'in all the countries of the world', they do not see themselves as forming with them 'one kind of people', nor do they attempt to establish any practical links with them.

Out of this brief description we can extrapolate the key features that characterise the non-convert diasporic modality or way of constructing Gypsyness - the one that, in this article, I use as base-line for comparison. Firstly, it lacks an overarching or allencompassing political structure or any institutions that would bring large numbers of Gitanos together, either on their own or with other Gypsies. Most importantly, the 
will for such structures is also absent. Secondly, sociable relations are characterised by the fear of violent interaction and by avoidance of unrelated Gitanos. Thirdly, unlike citizenship or nationality, Gypsyness is not imposed from above or from the centre, but rather is dependent on the performances of particular Gitano persons. Concomitantly, there is no concern with the size or location of other Gitano or Gypsy communities elsewhere. Fourthly, the past is disregarded as a source of shared identity, and downplayed throughout most spheres of social life (Gay y Blasco 2001). Lastly, this is a diasporic modality that, being premised on social and political fragmentation and on moral correspondence, involves also a strong egalitarian ethos. Gitanos strongly resist the imposition of authority from outside the patrigroup and even within it hierarchies and inequalities - beyond the basic difference in status between men and women - are constructed more on the basis of achievement than ascription (Gay y Blasco 1999, 2000).

\section{The Gitano diaspora. Secular transformations}

To the general public in the English-speaking world, the better known alternative to the mode of being a Gitano that I have just described is represented by the growing numbers of Roma NGOs and self-help groups who call for international recognition of minority status for the Roma, for the application of human rights to Roma throughout the world and, in some cases, for Roma political unity. The diasporic modality that they embody draws heavily on dominant western models of ethnicity, identity and personhood that contrast strongly with the ones I have described above for Jarana. It is very important to underline that none of these organisations has attempted to reach the Gitanos of the neighbourhood, and they therefore have no grassroots support there. The people of Jarana are predominantly unaware of their existence and their aims, even though the movement towards politicisation began to develop in Spain as early as the mid-1960s and, as elsewhere in Europe, has undergone a huge growth in the last few years, hand in hand with the expansion of the European Union.

Among these Roma NGOs, some focus primarily on improving the position of Gypsies within particular national contexts. In Spain, a good example is the Asociación Secretariado General Gitano, which came into being during the Franco regime and whose aims are:

To work for the full integration of Gypsy men and women into society; to promote the active participation of the Gitano community in its own development; to improve the public image of the Gitano people in society; and to disseminate the cultural values of the Gitano people within a multicultural society (bttp://wwweasgg.org/; my translation).

By contrast, others organisations, such as the International Romani Union, are explicit in calling for the political unification of Roma worldwide:

\section{ROMA FROM THE WHOLE WORLD UNITE}

Romani representatives from 44 countries met yesterday in Malmoe. One of the purposes of the meeting was to unite IRU, International Romani Union, and RNC, Roma National Congress. And it succeeded. This is a great day for us, says Victor Famulson, the chairman of the worldwide IRU. IRU represents 12 million Roma in the world. The president of the Spanish Romani Union, Juan de Dios Ramírez-Heredia, has got from NATO's General Secretary Javier Solana the certainty that the Alliance forces will protect the Roma ethnic minority living in Kosovo from any attack they 
could receive on the part of the ELK extremists. He also acceded to the request of the Spanish Romani organisation to have a meeting with him and with the presence of some Kosovian Roma, who know better than nobody (sic) the tragedy they are suffering (bttp://wwrw.unionromani.org).

This short news report from the website of the Romani Union indicates a way of imagining and creating 'the Roma people' as a particular kind of community or diaspora that is very different from the one I have described for Jarana. It calls for the practical unity of Gypsies/Roma everywhere ('Roma from the Whole World Unite'); it proposes an overarching transnational, global political framework in the form of the Romani Union and the Roma National Congress; and it assumes identity of interests and purposes of Roma worldwide so that a Gitano can challenge NATOs General Secretary about the situation of Roma in Kosovo. The latter's particular ethnic affiliation - the Gypsy subgroup to which they belong - is, significantly, not mentioned. And, indeed, it is the use of the term Roma to refer to Gypsies everywhere that encapsulates all these features.

The performative essence of Gypsy modes of identity- and community-building is recognised and elaborated by this Roma NGO - and with it, the notion that Gypsyness is always context-specific. As Vega Cortés says in the same website, '(o)ne is a Gitano in as much as one accepts and upholds the Gitano laws' (1974: 4; my translation), ${ }^{5}$ the set of unwritten customs that separates Gitanos not only from nonGypsies but also from other Gypsies. And yet, the emphasis is also heavily shifted towards a project of shared identity that transcends boundaries, both across nations and within the transnational Roma community itself. In particular, there is a movement away from emphasising the differences between Gitanos, Manuches, Rom and so on, that contrasts with the widespread non-activist practice of acknowledging other Gypsy groups as non-Gypsies while refusing to place them in the same moral slot as ego. Transnationally oriented activists, by contrast with the Gitanos of Jarana, attempt to capture the multiple Gypsy positions from which to face the world under one label and from a single, neutral standpoint (Williams 1984: 167ff.). What emerges is a conceptualisation of the Roma as a global diaspora, not unlike the Jewish one.

One of the most striking characteristics of this movement is therefore its heavy ideological and practical dependence on non-Gypsy political modalities and structures, a dependence which in fact transcends the very significant differences in aims and perspectives that characterise specific organisations. Indeed, the growing success of NGOs as diverse as the Asociación Secretariado General Gitano or the International Romani Union is premised on particular institutional supports of nonGypsy origin. These include participation in non-Roma political bodies; the creation of practical and imaginative links with Roma elsewhere and transcend barriers of ethnic affiliation, language and life-style; the production of written material in the dominant language of law and politics; and access to educational, economic and technological resources. Ultimately, the activist movement and the novel models of Gypsyness that it enables also rely to a large extent on recent changes in non-Gypsy attitudes, which are increasingly portraying these Roma attempts at self-legitimisation as acceptable.

5 'One is a Gitano in as much as one accepts and upholds the Gitano lares, because these laws have been shown to be good and positive for the whole of the Gitano people. They are laws that have allowed us to live in the midst of a hostile society, sustaining our cohesion as a group' (Vega Cortés 1997: 4; my emphasis and translation). 


\section{The Gitano diaspora. Pentecostal transformations}

In Jarana, where these forms of Roma political activism are unknown, it is through the growth of Gitano Pentecostalism that the Gitanos are developing a new diasporic modality. Like Roma activism, Gitano Pentecostalism represents a Gypsy attempt to transform the meaning and experience of Gypsyness both for Gypsies and for others. However, where activism is premised on non-Gypsy models of personhood - by which all persons become entitled to the same human rights, effectively working as equally valuable units of humanity - Pentecostalism fully maintains the Gitano belief in two kinds of persons, Gitanos and others, who are endowed with incommensurable moral differences and who are therefore differently positioned in the world (Gay y Blasco 1999). Gitano Pentecostalism thus continues to uphold the key Gitano ideological emphasis on the Gitanos' moral need to maintain their difference from the dominant non-Gypsy majority.

Like Roma activism, Gitano Pentecostalism is best conceptualised as an emergent mode of being in the world, both for the self and in terms of the networks of social relations that converts construct. Even though Gitano Pentecostalism was born in the mid-1960s, it is only in the last fifteen years that it has begun to undergo its greatest expansion. This means that, today, converts see themselves very much as initiating a new way of being a Gitano and as bringing about a complete transformation to the Gitano way of life. In fact, the Pentecostal and non-Pentecostal 'ways of being' (maneras de ser) - to use the Gitano terminology - compete with each other, and particular individuals, whether defining themselves as converts or not, often find themselves having to choose to interpret and portray their actions according to either ideal model.

Other clear parallels between the emergent Pentecostal and activist diasporic modalities become apparent when we consider the aleluya anti-drugs campaign that I describe below. At that event, as at other Pentecostal arenas, local converts from different razas came together both to worship and for sociable purposes, and with them were Gitanos from other areas of Spain and a handful of Gypsies from outside the country. The aim of the campaign was to address what is seen by many of the Gitanos who live in Madrid as the current greatest threat to the survival of the Gitanos as a 'people' (pueblo): the growing spread of drug-addiction among young men. As such, the campaign was seen as a step in the process of eventual redemption and unification of all Gitanos. In other words, the campaign showed up the converts' concern with transcending fragmentations and with achieving cohesion and social harmony among Gitanos, a concern that, albeit in a very different form, lies also at the core of the activists' aims and perspectives.

It is a summer evening and my first visit to Jarana after the end of my fieldwork. My friend Clara and her husband Lolo greet me warmly and tell me how lucky I am: it so happens that tonight a big anti-drugs Pentecostal service has been set up down in La Fresneda, the nearby neighbourhood where Gitanos live in tower blocks among the non-Gypsies. We arrive just as the service is starting. A platform has been erected in the middle of the local park, and there are about 150 Gitanos sitting in rows in front of it. To one side there is a family-sized camping tent: Clara tells me that, for two days now, a chain of prayer has been going on inside. We sit among the women while Lolo, who has been a pastor of the Church since his early twenties, takes his place amongst the male ministers and trainees on the platform. I notice that, although in the audience there are a good number of non-converts from several different razas, I am the only non-Gypsy present.

The pastor who is currently in charge of the church at La Fresneda opens up the service. $\mathrm{He}$ comes from outside Madrid, has no kin in the area, and was posted to La Fresneda about three months 
ago. He preaches for a short while to the accompaniment of shouts of ; Aleluya! and ;Si, miSeñor!, then asks the choir to start singing. The Gitanos, many of whom are sitting among non-kin, pray aloud and some start crying, speaking in tongues or prophesying. After the song, the key speaker delivers his sermon. He is a Portuguese pastor well known for his ability to cast out demons. In Portugal he has set up several anti-drugs campaigns. Clara tells me that many young men have converted and given up heroin with his help. He preaches for twenty minutes and then asks any local addicts present to come forward and declare that they accept Jesus as their personal saviour. A handful do. They are prayed over and some break down in tears or faint. The service goes on, blending preaching, music and prayer for another three hours whilst non-Gitano passers-by pay little or no attention to the proceedings.

By contrast with the way the non-converts of Jarana imagine and construct 'the Gitanos' or 'the Gitano people' as a particular kind of community, the Pentecostal pattern goes a long way towards emphasising unity and towards rejecting kin-based and political fragmentations as paths towards the realisation of Gypsyness. Activating links with Gitanos outside the kin group is of particular significance to aleluyas, who come together not only at lengthy daily services but also at anti-drugs campaigns and at summer trips to the river to celebrate baptisms. The converts who are most active within the Church - ministers, trainees and their families, but also others - often build up close relations with non-kin, and in the process transform the non-convert pattern of daily sociability: they visit each others' houses for coffee and prayer, go out to the fun park in same-sex groups or in sets of married couples, and even co-operate in economic activities. They also display an interest in establishing contact with unrelated Gitanos who live elsewhere in Madrid, in Spain, and even beyond, visiting churches in other neighbourhoods or provinces, and sometimes volunteering as missionaries to go to North Africa, the Canary Islands and South America, where many Gitanos migrated in the 1950s and 1960s. Every year thousands of converts come together in huge religious assemblies called convenciones, which are national or transnational in character, bringing together Gitanos and Gypsies from Spain, Portugal and France.

Most importantly, feuding as a method for structuring and dealing with conflict is rejected - at least rhetorically - by the members of the Church. Both during services and in more informal contexts, they tell endless stories about life-long enemies dramatically forgiving each other after embracing Pentecostalism: they pride themselves in dealing with confrontation through dialogue and reconciliation, rather than through revenge. Although this ideal is by no means always reached, when committed converts find themselves in the midst of a feud or a serious conflict they do attempt to put pressure on their kin to avoid revenge and escalation, and often call on pastors to act as mediators together with, or instead of, the 'men of respect'. It is on this undermining of feuding that the novel aleluya pattern of sociability is built: it is only when unrelated Gitanos are no longer perceived as being necessarily a threat that interacting more closely with them becomes possible.

The incipient aleluya way of organising relations among Gitanos goes a long way towards addressing those dimensions of 'the Gitano way of living' (la manera de vivir Gitana) that, over the last twenty years, have progressively become harder to sustain. ${ }^{6}$

6 My aim in this paragraph, and indeed in the article as a whole, is not to account for why Gitanos are converting to Evangelism. Rather, I want to investigate what happens to Gitano ways of organising social relations and to the imagined community that they sustain once conversion takes place. As part of this project I outline the ways in which the growth of Pentecostalism helps resolve evolving contradictions within the non-convert diasporic modality; I am grateful to a Social Anthropology anonymous reviewer for suggesting this avenue of enquiry. I am aware that conversion cannot be fully accounted for in these terms. 
As a woman from Jarana explained: 'Who wants to lose their house and end up in a field somewhere? And who wants to lose their permits for selling?' Indeed, since the 1960s and 1970s, the tendency has been for Gitanos to become concentrated, typically against their will, in the peripheries of the large cities (GIEMS 1976). It was during that period that the so-called 'rural exodus' took place: in response to the country's industrial development, hundreds of thousands of non-Gypsy migrants and with them tens of thousands of Gitanos left the countryside and resettled in the cities. Successive administrations first pushed the Gitanos into massive Gypsy-only shanty towns, and then compulsorily resettled them, frequently in large numbers and in isolated areas. Nowadays most Gitanos still have little or no choice over where to live. They are forcefully resettled by the local authorities in peripheral housing estates purpose-built for Gitanos or in deprived neighbourhoods where the ratio of Gitanos to Payos is very high (Gay y Blasco 2002). As San Román (1994: 102) argues, feuding as a problem-solving institution worked best in rural, pre-1960s Spain, when dispersal in small groups among the non-Gypsies was the norm, and when patrigroups that had to flee could relocate with ease. This is practically impossible today, when the Gitanos' access to housing is under the control of the local authorities and even the most informal of their modes of livelihood have become strictly regulated by the state. Moreover, there are the emotional consequences of living in fear of other Gitanos when getting away from them is not necessarily possible: Tía Rosa, in whose house I lived during fieldwork, often described bad nightmares in which herself or her children were involved in a feud.

It is against this background that converts challenge patrigroup affiliation as the only or even the main basis of intra-community relations. The Gitano-aleluya imagined community is still diffuse in its size and location, but it is no longer a community made up of aggregations of people who are the same and yet often hostile to the self, as happens in the non-convert world. Moreover, it is an imagined community whose very structural basis is the Church itself and, at its core, a new political hierarchy of roles and statuses. ${ }^{7}$ This hierarchy is meant to transcend barriers of kinship, region of origin and economic status and to bind converts in any particular area with Gitano and also more vaguely, other Gypsy converts elsewhere within a worldwide, God-given plan for action. It has a 'president' (presidente) at the top, 'regional delegates' (delegados regionales) below him, and then local pastors (pastores) and trainees (candidatos) at its lowest levels. Their wives take up parallel positions to deal with those issues that affect the women of the Church. ${ }^{8}$ The specific workings of this hierarchy are obscure to most converts as are the relation of the Church in Spain to the rest of the Gypsy Pentecostal movement outside Spain. However, all converts know that the regional delegate and the president keep a close eye on each local church and make pastors and their wives - whose numbers far exceed those of available churches - circulate between congregations with regularity.

To the people of Jarana it is clear that pastors are increasingly competing with the 'men of respect' for the positions of highest authority and prestige within the

7 I have discussed at length the gendered dimension of conversion processes elsewhere, dealing both with women (Gay y Blasco 1997; 1999) and with men (Gay y Blasco 1999; 2000).

8 All the pastors I know are married. It is extremely rare for Gitanos to remain single and the role of the pastor's wife (the pastora) is essential for the daily management of any local church. Moreover, there is no position of influence open to women outside the Church that would be parallel to that of the pastor's wife. 
community. ${ }^{9}$ The best known pastors - for example, those with a reputation for casting out demons, prophecy or oratory - are often called to mediate in serious conflicts, either on their own or with one or more 'men of respect'. This is the case even though these men tend to be considerably younger than the traditional mediators, and even though their knowledge of the 'Gitano laws' (leyes gitanas) and their experience of dealing with angry parties in the midst of heated disputes are limited. However, unlike young non-converts, who tend to fulfil those ideals of Gitano masculinity that focus on sexual promiscuity and physical bravery, young male converts model themselves upon the ideal figure of the 'man of respect' - a self-controlled, reliable, truthful older man. In so doing they also draw upon dominant Gitano discourses of prestige and authority, which focus on moral righteousness as the basis for ascribed male status (Gay y Blasco 1999; 2000). It is remarkable how convinced non-converts tend to be by their performance: non-convert mothers often push their daughters into attending the daily services regularly in the hope that they will catch the eye of a young aleluya. For their part, women whose husbands become pastors gain access to a whole new realm for the exercise of female influence and authority, a realm non-existent in the non-convert world. As pastoras they provide guidance and advice to the women of the Church, related or not. Like their men, they are often the recipients of the kinds of deference and respect that are usually reserved to much older women.

These transformations in ways of organising daily sociability, of dealing with conflict and of allocating prestige and authority demonstrate how converts are beginning to transform the very structure of Gitano socio-political relations. They are revising certain key institutions and developing new ones: by creating an ideal of social cohesion to be built upon the hierarchies of the Church, and by reaching out imaginatively to other Gitanos and Gypsies, aleluyas are in fact creating a new project for 'the Gitano people', or a new diasporic modality. This project is much closer to anthropological notions of 'society' as a cohesive body of institutions, statuses and roles than the ideals of community as commonality embraced by the non-converts.

In this sense it is particularly significant that, at the core of these Pentecostal innovations, lies a changed perception of the self and the group in time. The nonconverts of Jarana - like many other Gitanos and Gypsies elsewhere - put much conceptual work into downplaying the effect of the past on the present, and refuse to invoke the 'before' as a justification of the 'now' (Gay y Blasco 2001). This goes hand in hand with their emphasis on the person as the performer of the Gitano morality, the real creator of 'the Gitanos' as a people. Roma activists, by contrast, draw on nonGypsy academic theories and take up the notion that Gypsies come from India. In claiming for all Roma a land of origin and also a shared history of persecution and nomadism, Roma activists begin to move away from the performative model of identity to the same emphasis on historical and biological continuity that lies at the core of dominant Euro-American ethnotheories. Like the activists, the converts of Jarana look to the past but to claim that all Gypsies are Jews that became lost during

9 Pastors come from a wide variety of backgrounds. In Jarana I met pastors from wealthy Gitano families who lived in great comfort. There were others who barely managed to make a living and who in fact belonged to some of the poorest households in the neighbourhood. Some had relatives who earned their living through drug-dealing or other illegal activities; others did not. I met several pastors who themselves had been drug-addicts or alcoholics; but I also came to know others who had always had a reputation for respectability and self-control. 
the forty years of exile in the Sinai desert. As Jews, the Gitanos are a chosen people who now - through their conversion to Pentecostalism - are about to fulfil God's plan for humanity.

This novel interest in the past does not mean, however, that Gypsyness does not need to be performed or enacted in the 'now': salvation in the eyes of the aleluyas comes firstly through conversion and secondly through a changed way of life. Gypsyness still has to be performed by individual Gitanos - albeit now they must do so also by upholding the Gospel - and the person thus remains at the centre of the aleluyas' views of the Gitanos as a people. However, among the converts of Jarana the Bible has become the written codification of Gypsyness, and aleluyas constantly look for parallels between Gitano and Jewish customs as described in the Bible. The written word, consequently, has become extremely important: converts teach each other to read and write (the vast majority of Gitanos in Jarana are functionally illiterate), publish histories of the Iglesia de Filadelfia that are used for teaching purposes within the Church, and also publicise their activities through such media as videos and websites.

While Roma activism both mimics the way international politics are organised and models itself upon non-Gypsy paradigms of identity and personhood, the Iglesia de Filadelfia takes up non-Gypsy institutional models and notions, as I have just explained, but paradoxically rejects their most basic ideological premise - the notion that Gitanos and non-Gitanos are the same kind of moral person. In common with transnationally oriented Roma NGOs, the convert diasporic modality takes as its starting point the assertion of a common destiny for all Gitanos but - unlike Roma activism - it uses this assertion to exalt the uniqueness and superiority of Gitanos over non-Gypsies. This is because of the converts' sustained rejection of the moral and religious worth of non-Gypsies, even Pentecostal ones, a disposition that they share with their non-convert friends and relatives. This attitude is made strikingly clear in a home video that the men of the Jarana church put together during my fieldwork, which dramatises for teaching purposes the dangers of not embracing salvation. In the film, a Gitano man who refuses to accept Christ as his saviour comes back from work one day to find his house empty. On turning on the radio he hears a non-Gypsy presenter reporting that 'whole Gitano families have been seen ascending up to heaven on clouds'. The next scene is an image of Hell, populated by non-Gypsies and nonconvert Gitanos alike, the protagonist included. In this film, failing to convert is equated with the utter moral degradation of the non-Gypsies that Gitanos so often emphasise in their daily lives. By the same token, only Gitanos are saved. The Iglesia de Filadelfia thus aims not only to transform what being a Gitano is about, but to reinforce the moral barrier between Gitanos and non-Gypsies. To the aleluyas of Jarana, non-Gypsy Pentecostalism is a second-rate option for a second-rate group of people: when, some months into my fieldwork, I invited a non-Gypsy Pentecostal pastor to visit Jarana's church, he was not asked to preach as a visiting Gitano pastor would have been, and the congregation remained very reluctant to pay him and his wife any attention or engage in conversation with them.

\section{Some conclusions}

What, then, is the significance of the Iglesia de Filadelfia as an emergent diasporic modality? In what ways does it replicate the effects of the work being done by Roma activists throughout Europe? Do the similarities between the two movements mean 
that Gypsies everywhere are engaging with the complexities and tensions of the contemporary world in the same ways? Indeed, both the Roma NGOs and the Iglesia de Filadelfia wish to reformulate the meaning of Gypsyness and have turned to the nonGypsy world for instruments through which to dramatise their respective reformulation: through their efforts, Gypsyness is becoming more easily comprehensible to the non-Gypsies. But there is a clear difference between the two movements. By embracing so fully the ideological premises about personhood and the organisational structures prevalent in the non-Gypsy sphere of international identity politics, Roma activism runs the risk of reducing Gypsyness to 'its minimal cultural prop', to use San Román's phrase (1986: 203), akin to a badge that comes to symbolise nothing but itself. Activists not only adopt the institutional supports for identity offered by the nonGypsies; they also rephrase the contents of that identity on the basis of non-Gypsy values and cultural models. Thus, the radical ethnocentrism of the Gitanos is abandoned and the Roma become a 'persecuted ethnic minority' which must be accommodated within the political structures of a unified Europe. Gitano distinctiveness becomes 'the Gitano culture' and replaces the clear awareness of Gitano moral superiority that drives the lives of the people of Jarana and their particular forms of resistance to encapsulation into the dominant population.

By contrast with the activists, the aleluyas of Jarana refuse to compromise what, in their eyes, makes them Gitanos: their essential difference from the non-Gypsies. They and their non-convert neighbours and relatives reject the label of 'ethnic minority' that is so important to the activist discourse: to them, it is the Gitanos that occupy the centre of the world, and the non-Gypsies that are marginal and peripheral. The implications of this self-conceptualisation are, I believe, essential to understanding Gitano Pentecostalism as a kind of politico-religious diaspora. On the one hand, in tandem with the spread of Gitano Pentecostalism, new political structures are radically transforming the pattern of life in Jarana and also how the Gitanos who live there think of themselves, both vis-à-vis other Gitanos and Gypsies and vis-à-vis the rest of the world.

These Gitanos are downplaying the importance of the patrilineal organisation that has provided the - albeit comparatively minimal - structural support for their particular kind of community for the last 500 years (San Román 1994), and are beginning to act as a 'people' in terms that are recognisable to the non-Gypsies that surround them (Williams 1991). In so doing, they are refashioning themselves as members of a new Gitano-Pentecostal diaspora. On the other hand, the purpose to which these new concepts and institutions are put is, unlike in the activist case, the perpetuation of Gypsyness not only as a distinct 'identity' or 'minority culture' but as a way of life premised on ideas about personhood that are not easily reducible to the non-Gypsy, dominant ones - a way of life that cannot be reduced to a badge, but which sets Gitanos apart from and above the non-Gypsies.

It is important to keep in mind that Jarana itself is a testing ground where two alternative models of Gypsyness are being tried out. At first sight, especially after an evening at the local church, watching and listening to the enthusiasm of the converts, it is tempting to assume that Gitano Pentecostalism and Gypsyness will soon, as the aleluyas predict, become synonymous, at least in the poorer fringes of Madrid. And yet, although it is clear that the Iglesia de Filadelfia is spreading at an extremely rapid pace and extending its influence over the lives of the growing numbers of Gitanos, its future is not altogether clear. Many people in Jarana find the gregariousness of the 
Church grating, and its dogmas too overbearing and uncompromising. They and others are likely to hold onto the fragmentation and dispersal precisely to resist and challenge the vision that Evangelists propose for 'the Gitano people'.

Paloma Gay y Blasco

School of Anthropological Studies

14 University Square

The Queen's University of Belfast

Belfast BT7 1NN

Northern Ireland

p.gay-y-blasco@qub.ac.uk

\section{References}

Anderson, B. 1991. Imagined communities. Reflections on the origins and spread of nationalism. London: Verso.

Anta Félez, J. L. 1994. Donde la pobreza es marginación. Un análisis entre Gitanos. Barcelona: Editorial Humanidades.

Cano, L. 1981. Un Pentecostés en el siglo XX. Sabadell: Cano.

Colin, C., and E. Campbell. 2000. "“Gypsy invasion”: A critical study of newspaper reactions to Czech and Slovak Romani asylum seekers in Britain'. Romani Studies 10: 23-48.

Gamella, J. F. 1996. La población Gitana en Andalucía. Un estudio exploratorio de sus condiciones de Vida. Sevilla: Junta de Andalucía.

Gay y Blasco, P. 1997. 'Etre une vraie femme Gitane. La politique du couple marié et la situation des femmes chez les Gitans Castillans à Jarna (Madrid).' Études Tsiganes 10: 29-46.

1999. Gypsies in Madrid. Sex, gender and the performance of identity. Oxford: Berg.

2000. 'The politics of evangelism. Hierarchy, masculinity and religious conversion among Gitanos'. Romani Studies 10: 1-22.

2001 ' "We don't know our descent". How the Gitanos of Jarana manage the past'. Journal of the Royal Anthropological Institute 7: 631-47.

2002 (in press). "This is not a place for civilised people". Isolation, enforced education and resistance among Spanish Gypsies', in A. Bashjord and C. Strange (eds.), Isolation. Places and practices of exclusion. London: Routledge.

Gellner, E. 1983. Nations and nationalism. Oxford: Blackwell.

GIEMS (Equipo). 1976. Los Gitanos al encuentro de la ciudad. Del chalaneo al peonaje. Madrid: Cuadernos Para el Diálogo.

Jordán Pemán, F. 1990. Los Aleluyas. Madrid: Secretariado Nacional Gitano.

Leblon, 1985. Los Gitanos de España. Madrid: Gedisa.

Liégeois, J. P. 1994. Roma, gypsies, travellers. Strasbourg: Council of Europe.

López Varas, M. L., and G. Fresnillo Pato. 1995. Margen y periferia. Representaciones ideológicas de los conflictos urbanos entre payos y Gitanos. Madrid: Asociación Secretariado Nacional Gitano.

Lucassen, L. 1991. 'The power of definition. Stigmatisation, minoritisation and ethnicity illustrated by the history of gypsies in the Netherlands', Netherlands Journal of Social Sciences 27: 80-91.

Mayall, D. 1988. Gypsy-travellers in nineteenth-century society. Cambridge: Cambridge University Press.

Okely, J. 1983. The Traveller-Gypsies. Cambridge: Cambridge University Press.

Sánchez Ortega, M. H. 1986. 'Evolución y contexto histórico de los Gitanos Españoles', in T. San Román (ed.), Entre la marginación y el racismo. Reflexiones sobre la vida de los Gitanos. Madrid: Alianza.

San Román, T. 1986. 'Reflexiones sobre marginación y racismo', in T. San Román (ed.), Entre la marginación y el racismo. Reflexiones sobre la vida de los Gitanos. Madrid: Alianza.

1994. La differencia inquietant. Velles i noves estrategies culturals dels Gitanos. Barcelona: Alta Fulla. 
Stewart, M. 1997. The time of the gypsies. Boulder: Westview Press.

Vega Cortés, A. 1997. Los Gitanos en España. Downloaded 16 June 2000 from http://www.unionromani. $\mathrm{org} /$ histo.htm.

Wilks, R. 1995. 'Learning to be local in Belize. Global systems of common difference', in D. Miller (ed.), Worlds apart. Modernity through the prism of the local. London: Routledge.

Williams, P. 1984. Marriage Tsigane. Une cérémonie de fiançailles chez les Rom de Paris. Paris: L'Hamarttan Selaf.

1991. 'Le miracle et la necessité. À propos du developpement du Pentecotisme chez les Tsiganes'. Archives de Sciences Sociales des Religions 73: 81-98. 